\title{
The NOD1 and NOD2 in mandarinfish (Siniperca chuatsi): molecular characterization, tissue distribution, and expression analysis
}

Tiantian Gu, Lu Lu, Jingwen Wang, Lili Tian, Wenzhi Wei, Xinsheng Wu, Qi Xu(i) and Guohong Chen*

\begin{abstract}
Background: NOD-like receptors (NLRs) are a family of cytoplasmic pattern recognition receptors (PRRs), of which NOD1 and NOD2, are the main representative members. Many investigations have focused on the role of NOD1 and NOD2 in the innate immune response in Cypriniformes and Siluriformes. As an important economic fish in Perciformes, little is known about the function of NOD1 and NOD2 in mandarinfish (Siniperca chuatsi).

Results: The full-length NOD1 and NOD2 cDNA sequence was obtained using reverse transcription polymerase chain reaction (RT-PCR) and rapid amplification of CDNA ends (RACE). The mandarinfish NOD1 and NOD2 CDNA sequences contain $3247 \mathrm{bp}$ and $3257 \mathrm{bp}$, and encode 918 amino acids and 988 amino acids, respectively. Multiple sequence alignments showed that $\mathrm{mNOD} 1$ and $\mathrm{mNOD2}$ share high similarity with that from other vertebrates. RT-PCR analysis revealed that relatively high levels of mNOD1 and mNOD2 mRNA were detected in gill and head kidney tissues, compared with the heart, spleen, liver, muscle, and intestine. In addition, the relative levels of $\mathrm{mNOD1}$ and $\mathrm{mNOD2}$ transcripts were significantly upregulated in three tissues when the fishes were challenged with LPS and Poly I:C, interestingly, the NOD1 mRNA got peaked earlier than NOD2 after LPS induction in the spleen, gill, and head kidney, and during Poly l:C treatment, the NOD2 mRNA got peaked at $8 \mathrm{~h}$ in spleen and gill, while NOD1 showed significant higher expression at $24 \mathrm{~h}$ post infection, besides, in head kidney, the NOD2 mRNA showed a great increasing trend and NOD1 got peaked at $16 \mathrm{~h}$. Therefore the mNOD1 and mNOD2 may act differently within different tissues in different time during antiviral and antibacterial defense.
\end{abstract}

Conclusions: These results revealed the dynamic mNOD1 and mNOD2 expression during viral and bacterial infections, which suggested the NOD1 and NOD2 play important roles in innate immune of mandarinfish.

Keywords: Mandarinfish, NOD1, NOD2, Gene expression, LPS, Poly (I:C)

\section{Background}

In vertebrates, the innate immune system is the fundamental defense mechanism, and plays a beneficial role in defending against invasion $[1,2]$. The innate immune system rapidly recognizes conserved pathogen associated molecular patterns (PAMP) via the presence of the host's own pattern recognition receptors (PRRs). At present, PRRs, which have been extensively studied, include

\footnotetext{
* Correspondence: xuqi@yzu.edu.cn; ghchen@yzu.edu.cn

Key Laboratory of Animal Genetics \& Breeding and Molecular Design of Jiangsu Province, Yangzhou University, Yangzhou 225009, People's Republic
} of China

(c) The Author(s). 2018 Open Access This article is distributed under the terms of the Creative Commons Attribution 4.0 International License (http://creativecommons.org/licenses/by/4.0/), which permits unrestricted use, distribution, and reproduction in any medium, provided you give appropriate credit to the original author(s) and the source, provide a link to the Creative Commons license, and indicate if changes were made. The Creative Commons Public Domain Dedication waiver (http://creativecommons.org/publicdomain/zero/1.0/) applies to the data made available in this article, unless otherwise stated.

Toll-like receptors (TLRs), retinoid acid-inducible gene-1 (RIG-I)-like receptors (RLRs), NOD-like receptors (NLRs), and DNA receptors. Studies have increasingly shown that RLRs and TLRs play an important role in the innate immunity of the organism and form the first line of defense against infectious pathogens [3-6]. Unlike TLRs and RLRs, NLRs are a recently identified large group of the intracellular PRR family characterized by multi-domain proteins, which contain an $\mathrm{N}$-terminal protein-protein binding domain such as the caspase recruitment domain (CARD), pyrin (PYD), or baculovirus inhibitor of apoptosis repeat (BIR) domain, in 
addition to a central nucleotide oligomerization (NACHT) domain and a C-terminal leucine-rich repeat (LRR) domain [7-10].

However, the NLRs do not contain a signal peptide or transmembrane domain, which indicate their locations in the cytosol. The C-terminal LRR domain is the potential ligand recognition site and the NACHT domain mediates self-regulation and oligomerization. The N-terminus is responsible for protein-protein interaction, signal transduction and initiation of the downstream immune cascade $[11,12]$. Based on the specific $\mathrm{N}$-terminal domain present, NLRs are divided into three subfamilies including NODs (containing the CARD domain), NALPs (containing the PYR domain) and NAIPs (containing the BIR domain) [10, 13]. Both of NOD1 and NOD2 are part of NODs subfamily with CARD, NACHT and LRR, which share three functional domains in mammals [14]. Among them, NOD1 contains an $\mathrm{N}$-terminal CARD domain, but NOD2 possesses two Nterminal CARD domain [15]. Previous studies have proved that NOD1 and NOD2 recognized bacterial and viral products through their C-terminal LRRs in mammals [16, 17]. Although the adaptive immune system of fish has well been developed, which can produce antibody response against infection. Innate immunity also plays an important role in protection against disease in fish. Some studies have found that after lipopolysaccharide (LPS) or polyriboinosinic polyribocytidylic acid (Poly (I:C)) stimulation, the expression of NOD1 and NOD2 was significantly upregulated in grouper fish [18], rainbow trout [19], carp [20], mrigal [21], catfish [22] and goldfish [23]. Similar results were also found in the spleen tissue of grass carp [24]. Upon ligand recognition, both NOD1 and NOD2 recruit RIPK to the receptors via CARD-CARD interactions, which lead to the activation of NF-kB and MAPK pathways [25]. The activation of NF-kB and MAPK mediated by NOD1 and NOD2 could induce transcription and production of inflammatory mediators and antimicrobial peptides, and induce apoptosis [15, 26]. Therefore, the NOD1 and NOD2 genes play an important role in the resistance of fish to the invasion of pathogenic microorganisms.

Among carnivorous freshwater fish, mandarinfish (Siniperca chuatsi), is a precious aquaculture species in China, with high economic value, but it is very sensitive to bacterial and viral infection. In recent years, outbreaks of disease epidemics such that of infectious spleen and kidney necrosis virus (ISKNV) [27, 28] and other epidemic diseases, such as Iridovirus $[29,30]$ and EHNV [31], have caused serious damage to the freshwater aquaculture industry in China; however, there have been few reports of the function of NOD1 and NOD2 genes against bacteria and virus in mandarinfishes. Based on this background, we performed the molecular cloning and characterization of the mandarinfish NOD1 and NOD2 genes and analyzed their expression levels during LPS and Poly (I:C) treatment in vivo. These data might facilitate a better understanding of the role of NOD1 and NOD2 in bacterial and viral infections, which is beneficial not only to the understanding of innate immunity mechanisms in mandarinfish, but also to monitor the disease occurrence in the aquatic culture industry.

\section{Methods}

\section{Tissues}

A total of fifty-seven mandarinfishes with 400-600 $\mathrm{g}$ in body weight were obtained from the the Gaoyou Dongshi Special Aquatic Products Company (Yangzhou, China). Fish were kept in aquarias with a flowthrough water system and aerated freshwater at $29{ }^{\circ} \mathrm{C}$. Tissues, including heart, liver, spleen, gill, head kidney, muscle, and intestine, were collected from three healthy mandarinfishes. Tissue samples were harvested and immediately snap-frozen in liquid nitrogen and stored at $-80{ }^{\circ} \mathrm{C}$ until needed. Total RNA was extracted from all tissues with TRIZOL (Invitrogen, Carlsbad, CA, USA).

\section{In vivo challenge experiments}

Fifty-four mandarinfishes were randomly divided into three groups, the eighteen fishes were injected with 500 $\mu \mathrm{l}$ Poly (I:C) (1 mg/mL) (Invivogen, CA, USA), the eighteen fishes were treated with $400 \mu \mathrm{l}$ LPS $(1 \mathrm{mg} / \mathrm{mL})$ (Sigma, MO, USA), and the others were injected with saline, respectively. No fish treated with LPS or Poly (I:C) died At 0, 2, 4, 8, 16, $24 \mathrm{~h}$ after injection, spleen, gill, and head kidney tissues were collected from three fish. Tissue samples were harvested and immediately snap-frozen in liquid nitrogen and stored at $-80{ }^{\circ} \mathrm{C}$ until needed.

\section{Cloning of $\mathrm{mNOD} 1$ and $\mathrm{mNOD2}$ cDNA}

Total RNA was isolated from the spleen of healthy mandarinfish with TRIzol (Invitrogen, USA) according to the manufacturer's instructions, and the quality of the isolated RNA was assessed by visualizing the ribosomal RNA bands after electrophoresis on a 1.0\% agarose gel. The PrimeScript ${ }^{\mathrm{Tm}}$ 1st Strand cDNA Synthesis Kit (TAKARA, Dalian, China) was used according to the manufacturer's instructions with $1 \mu \mathrm{g}$ of total RNA as a template to produce cDNA. Based on the conserved sequences of Ictalurus punctatus, Larimichthys crocea, Lateolabrax japonicas, and Paralichthyidae, forward and reverse primers for $\mathrm{mNOD} 1$ and $\mathrm{mNOD} 2$ were designed to obtain the internal region (Additional file 1: Table S1). For all genes, the polymerase chain reaction (PCR) amplification was conducted using LA Taq (TAKARA) with the following conditions: $94{ }^{\circ} \mathrm{C}$ for $5 \mathrm{~min}, 35$ cycles of $94{ }^{\circ} \mathrm{C}$ for $30 \mathrm{~s}, 52{ }^{\circ} \mathrm{C}$ for $30 \mathrm{~s}$, and $72{ }^{\circ} \mathrm{C}$ for $2 \mathrm{~min}$, followed by 
one cycle of $72{ }^{\circ} \mathrm{C}$ for $10 \mathrm{~min}$. Rapid amplification of cDNA ends (RACE)-ready first-strand cDNA was synthesized using a Takara RACE cDNA amplification kit (Takara, China) in accordance with the manufacturer's protocol and RACE primers were designed according to the manufacturer's protocol (Additional file 1: Table S1). Subsequently, RACE was performed on the $5^{\prime}$ and $3^{\prime}$ ends of the $\mathrm{mNOD} 1$ and $\mathrm{mNOD} 2 \mathrm{cDNA}$. The sequences of $\mathrm{mNOD} 1$ and $\mathrm{mNOD} 2$ were submitted to GenBank under the accession numbers KY974318 and KY974317, respectively. All the primer sequences mentioned above are shown in Additional file 1: Table S1.

\section{Sequence alignment and homology analysis}

A phylogenetic tree was constructed based on the deduced amino acid sequences using the Neighbour-Joining (NJ) algorithm within MEGA 6.0 program and a multiple sequence alignment was created by AlignIR V2.0. Clustal Omega (http://www.ebi.ac.uk/Tools/msa/clustalo/) was performed to construct multiple sequence alignments of the amino acid sequences of mNOD1 and mNOD2 proteins. The conserved domains of mNOD1 and mNOD2 were predicted using the NCBI Conserved Domains Database Tools (CDD Tools) (https://www.ncbi.nlm.nih.gov/ Structure/cdd/).

\section{Expression of mNOD1 and mNOD2 mRNA in tissues}

Total RNA was extracted from the tissues (heart, liver, spleen, gill, head kidney, muscle, and intestine) of healthy mandarinfish using TRIZOL (Invitrogen), $1 \mu \mathrm{g}$ RNA was used with gDNase (TIANGEN, China) during reverse transcription for RT-PCR. The process included an initial phase at $42{ }^{\circ} \mathrm{C}$ for $3 \mathrm{~min}$ and then incubation at $42{ }^{\circ} \mathrm{C} 15 \mathrm{~min}$ followed by $95{ }^{\circ} \mathrm{C}$ for $3 \mathrm{~min}$. The cDNA stored at $-80{ }^{\circ} \mathrm{C}$. The primers are listed in Additional file 1: Table S1. The reaction conditions included 1 cycle at $95{ }^{\circ} \mathrm{C}$ for $5 \mathrm{~min}$, followed by 35 cycles of $94{ }^{\circ} \mathrm{C}$ for $30 \mathrm{~s}, 60{ }^{\circ} \mathrm{C}$ for $30 \mathrm{~s}$, and $72{ }^{\circ} \mathrm{C}$ for $30 \mathrm{~s}$, and a final incubation at $72{ }^{\circ} \mathrm{C}$ for $10 \mathrm{~min}$. The products of PCR were separated on $2 \%(w / v)$ agarose gels, and the $\beta$-actin gene was used as an internal standard for relative expression levels.

\section{Expression of mNOD1 and mNOD2 mRNA following poly (I:C) and LPS treatment in tissues}

RNA extraction and cDNA synthesis were performed as described above. QuantStudio 5 (Applied Biosystems, Thermo Fisher Scientific, USA) was used to perform the assay, and $\mathrm{qPCR}$ was performed using SYBR Green Master Mix (Vazyme, Nanjing, China) to determine the pattern of mNOD1 and mNOD2 mRNA expression after challenge with Poly (I:C) and LPS, the following reaction conditions were conducted including 1 cycle at $95{ }^{\circ} \mathrm{C}$ for $5 \mathrm{~min}$, followed by 30 cycles of $95{ }^{\circ} \mathrm{C}$ for $10 \mathrm{~s}$ and $60{ }^{\circ} \mathrm{C}$ for $30 \mathrm{~s}$, and a final cycle of $95{ }^{\circ} \mathrm{C}$ for $15 \mathrm{~s}, 60{ }^{\circ} \mathrm{C}$ for $60 \mathrm{~s}$, and $95{ }^{\circ} \mathrm{C}$ for $15 \mathrm{~s}$. The relative expression of mRNA was calculated using the $2^{-\Delta \Delta C T}$ method, and the $\beta$-actin gene was used as an internal control.

\section{Statistical analysis}

Data from all experiments are expressed by mean \pm standard error. A database was established in Excel 2003 and the data were statistically analyzed with SPSS 13.0 using the one-way ANOVA Duncan method. P-values below 0.05 were considered statistically significant.

\section{Results}

cDNA cloning and sequence analysis of mandarinfish NOD1 and NOD2

Using RT-PCR and RACE technology, the full-length sequence of $\mathrm{mNOD1}$ was obtained, which included a 124-bp 5' UTR, a 2757-bp open reading frame (ORF) and a 366-bp 3' UTR, and encodes 918 amino acids. The mNOD2 cDNA was cloned with 124-bp 5' UTR, a 2967-bp ORF encoding 988 amino acids, and a 166-bp 3' UTR. The primers used are shown in Additional file 1: Table S1. The sequences of $\mathrm{mNOD1}$ and $\mathrm{mNOD2}$ were submitted to GenBank (GenBank accession number KY974318 and KY974317, respectively). Furthermore, using the NCBI Conserved Domains Database Tools (CDD Tools) to predict the conserved domains of mNOD1 and mNOD2, we found that mNOD1 has one CARD domain (residues 13-97), one NACHT domain (residues 189-360), and seven LRRs (residues 670-868) (Fig. 1a), whereas mNOD2 includes two CARD domains (residues 7-91 and 115-195), one NACHT domain (residues 273-443), and six LRRs (residues 757-979) (Fig. 1b). A comparison of the coding sequence (CDS) and amino acid sequence of mNOD1 and mNOD2 to the NOD1 and mNOD2 genes of other species, including multiple alignments and amino acid sequence, are shown in Fig. 1a and b, respectively.

\section{Phylogenetic analysis}

To evaluate the molecular evolutionary relationships between mNOD1 and mNOD2 and NODs orthologs in other vertebrates, a phylogenetic tree was constructed based on the amino acid sequences of mammalian, avian, and fish NODs. The inferred phylogeny of the NOD1 and NOD2 genes is presented in two distinct clusters (Fig. 2). Mandarinfish NOD1 was in the same branch as that of grouper, bastard halibut, grass carp, and zebrafish, but had a distant evolutionary relationship with mammals and birds, illustrating the closer relationships between mandarinfish NOD1 and those of other fish species. Mandarinfish NOD2 was most closely related to those of grouper, fugu, rainbow trout, and zebrafish, in a branch separate from that of the mammals. 


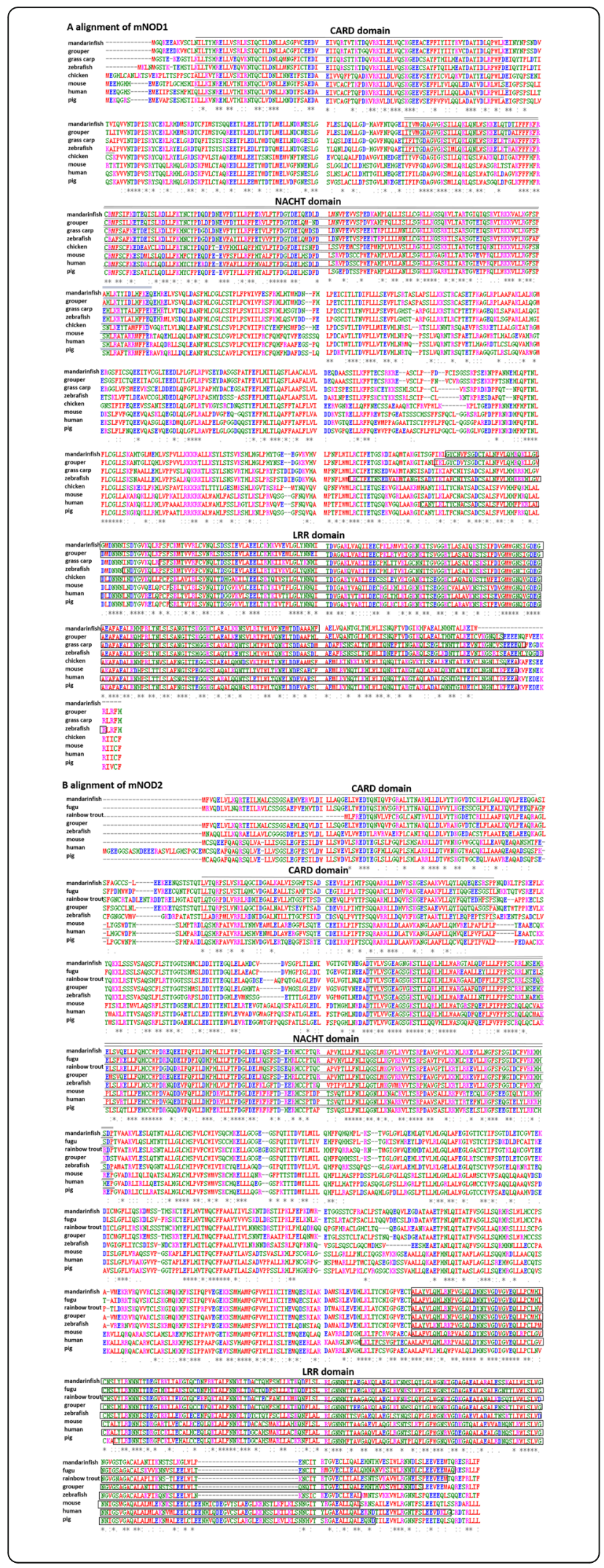

Fig. 1 (a) Multiple alignments of NOD1 protein sequences from mouse (NM 172729.3), human (NM_006092.3), pig (NM 001114277.1), chicken (NM_001318438.1), zebrafish (XM_002665060.6), grouper (JX220894.1), grass carp (FJ937972.1), and mandarinfish (KY974318). (b) Multiple alignments of NOD2 protein sequences from mouse (NM_145857.2), human (XM_017023536.1), zebrafish (NM_001328044.1), pig (NM_001105295.1), fugu (NM_001042448.1), rainbow (NM_001201555.1), grouper (JX220895.1), and mandarinfish (KY974317). Abbreviations: CARD: caspase recruitment domain, NACHT: nucleotide binding/oligomerization domain, LRR: leucine-rich repeats Asterisks represent identical amino acids, and The symbols "." or ":" denote conservative substitutions

\section{Tissue expression profiles of $\mathrm{mNOD} 1$ and $\mathrm{mNOD2}$}

To determine the tissue expression levels of $\mathrm{mNOD1}$ and $\mathrm{mNOD2}$, RT-PCR was performed. mRNA expression of $\mathrm{mNOD} 1$ and $\mathrm{mNOD} 2$ was detected in all seven tissues collected. We found that $\mathrm{mNOD1}$ and $\mathrm{mNOD2}$ mRNAs were highly expressed in heart, spleen, gill, and head kidney, particularly in head kidney and gill, and the expression of $\mathrm{mNOD} 2$ was generally higher than that of $\mathrm{mNOD1}$ in these four tissues. On the other hand, relatively low expression of $\mathrm{mNOD} 1$ and $\mathrm{mNOD} 2$ was detected in the liver, muscle, and intestine (Fig. $3 a$ and b).

\section{Expression of $\mathrm{mNOD} 1$ and $\mathrm{m} N O D 2$ in tissues after LPS and poly $(\mathrm{I}: \mathrm{C})$ treatment}

To further determine the regulation of $\mathrm{mNOD1}$ and $\mathrm{m} N O D 2$ expression by LPS or Poly (I:C) in vivo, different tissues from treated and untreated groups were collected following treatment with saline, LPS or Poly (I:C). The mRNA expression levels of $\mathrm{mNOD1}$ and $\mathrm{mNOD} 2$ in different tissues were detected by qRT-PCR at various time points after injection $(0,2,4,8,16$ and $24 \mathrm{~h})$. The mRNA expression of mNOD1 and mNOD2 showed no significant change in different tissues when injecting saline. And the relative transcript levels of $\mathrm{mNOD} 2$ in spleen and head kidney were upregulated at $16 \mathrm{~h}$ after LPS stimulation and then gradually decreased, and in gill mNOD2 mRNA showed a gently trend; however, the peak time of mNOD1 mRNA appeared $2 \mathrm{~h}$ after the infection in spleen and gill, and $8 \mathrm{~h}$ in head kidney, and in spleen, the mNOD1 mRNA got peaked again at $16 \mathrm{~h}$ (Fig. 4d, e, f). However, following Poly (I:C) injection, the expression levels of $\mathrm{mNOD} 1$ and $\mathrm{mNOD} 2$ in these three tissues showed a persistently increased trend (Fig. 4g, h, i), with the exception of $\mathrm{mNOD} 2$ in the spleen (Fig. 4g) and mNOD1 in the head kidney (Fig. 4i).

\section{Discussion}

Innate immunity is the first line of defense against infectious pathogens, and NLRs, which function as intracellular PRRs, play an important role in resistance to bacterial and viral infection [24, 32, 33]. In human [17], the deficiency of NOD2 would cause Crohn's disease and 


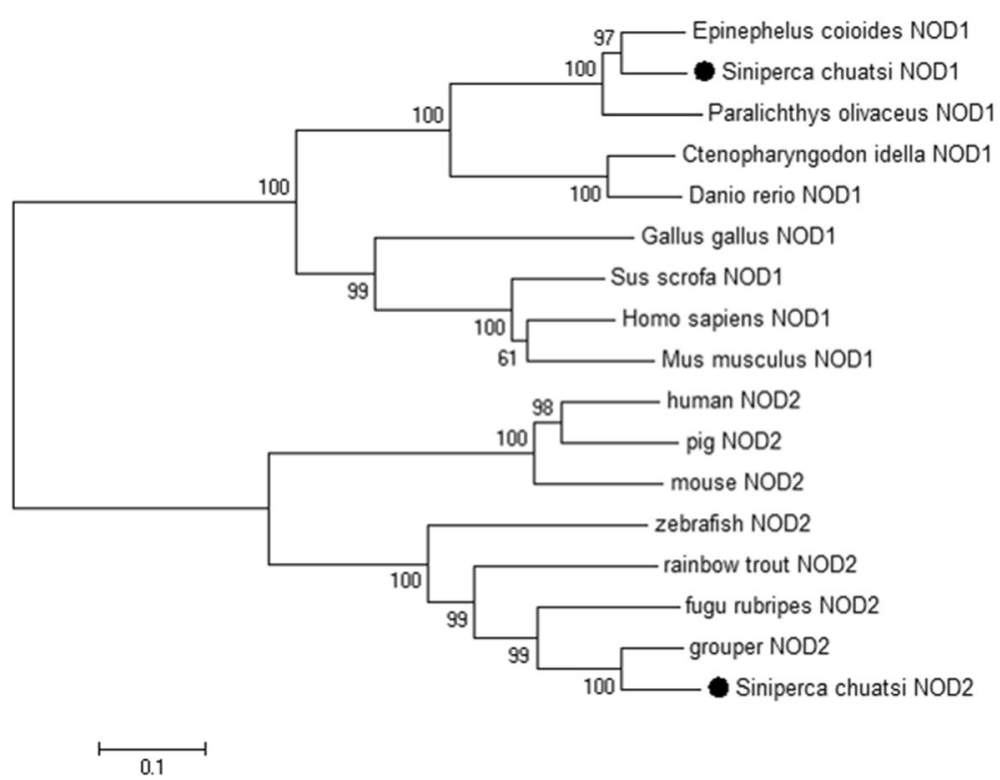

Fig. 2 Phylogenetic analysis of avian, mammalian, and fish NOD1 and NOD2 was carried out. The tree was constructed by the neighbor-joining tree method using amino acid sequences aligned with MEGA6. The bar indicates the bootstrap value (\%)

in grass carp [24], NOD1 and NOD2 could be upregulated by different immunostimulants. However, almost nothing is known about the homeostatic or pathogen-induced expression patterns of NLR transcripts in mandarinfish.

To better understand the mechanism of NOD1 and NOD2 function in mandarinfish against pathogenic microorganisms, we isolated and identified the NOD1 and NOD2 cDNA sequence and characterized their sequence. The conserved domains of mandarinfish predicted by the CCD tool (Fig. 1a and b) showed that both of them had similar conserved domains containing

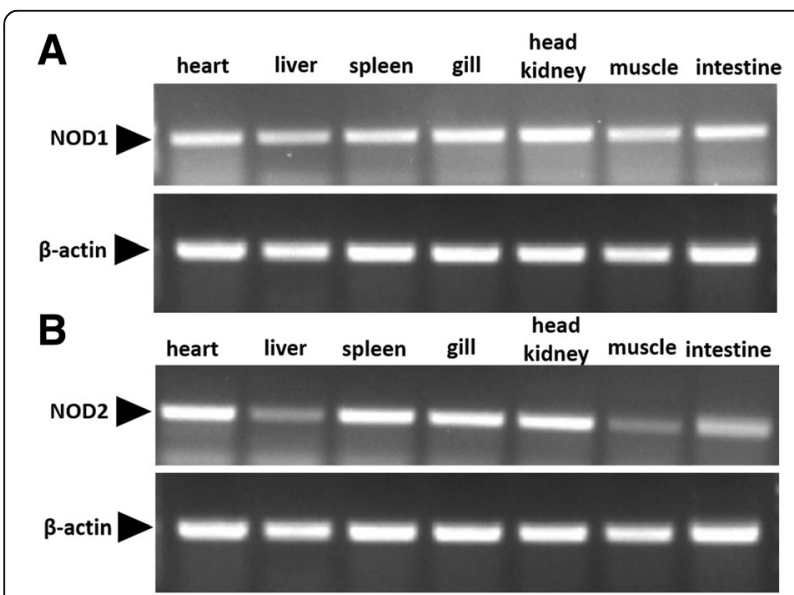

Fig. 3 mRNA expression of $m N O D 1$ (a) and mNOD2 (b) mRNA in various tissues. $\mathrm{mNOD1}$ and $\mathrm{mNOD2}$ were determined using RT-PCR and compared to the expression of $\beta$-actin. Tissues of three healthy fishes analyzed include heart, liver, spleen, gill, head kidney, muscle, and intestine
CARD-NACHT-LRR domains. NOD2 had one more CARD domain than NOD1, and NOD1 had seven LRRs, whereas NOD2 only had six; however, both of them had a similar structure to grouper and miiuy croaker $[18,34]$. The high conservation of LRR domains in NOD1 and NOD2 implied that they may possess similar functional properties as those of other fishes in the recognition of pathogenic microorganisms and viruses [18]. Furthermore, amino acid homology analysis and phylogenetic analysis of mandarinfish NOD1 and NOD2 revealed that they shared high similarities with NOD1 and NOD2 proteins from other teleost fishes, but low similarities with those of mammals and birds. Our results showed that NOD1 and NOD2 were evolutionarily conserved not only in terms of their protein sequences but also in terms of functionally significant domains.

In healthy mandarinfish, the NOD1 and NOD2 genes were widely expressed in all the tissues collected. RT-PCR analysis revealed that $\mathrm{mNOD1}$ and $\mathrm{mNOD} 2$ mRNA were expressed at higher levels in the heart, spleen, gill, and head kidney than in other tissues, particularly in the head kidney and gill; moreover, the expression of $\mathrm{mNOD} 2$ was generally higher than that of mNOD1 in these four tissues (Fig. 3a and b), although this result was markedly different from that observed in grouper [18], grass carp [24], mrigal [21] and channel catfish [35]. In grass carp, the highest expression of NOD1 was in the liver, whereas NOD2 was highly expressed in head kidney [24]. In mrigal, significant expression of NOD1 was detected in the liver, whereas 


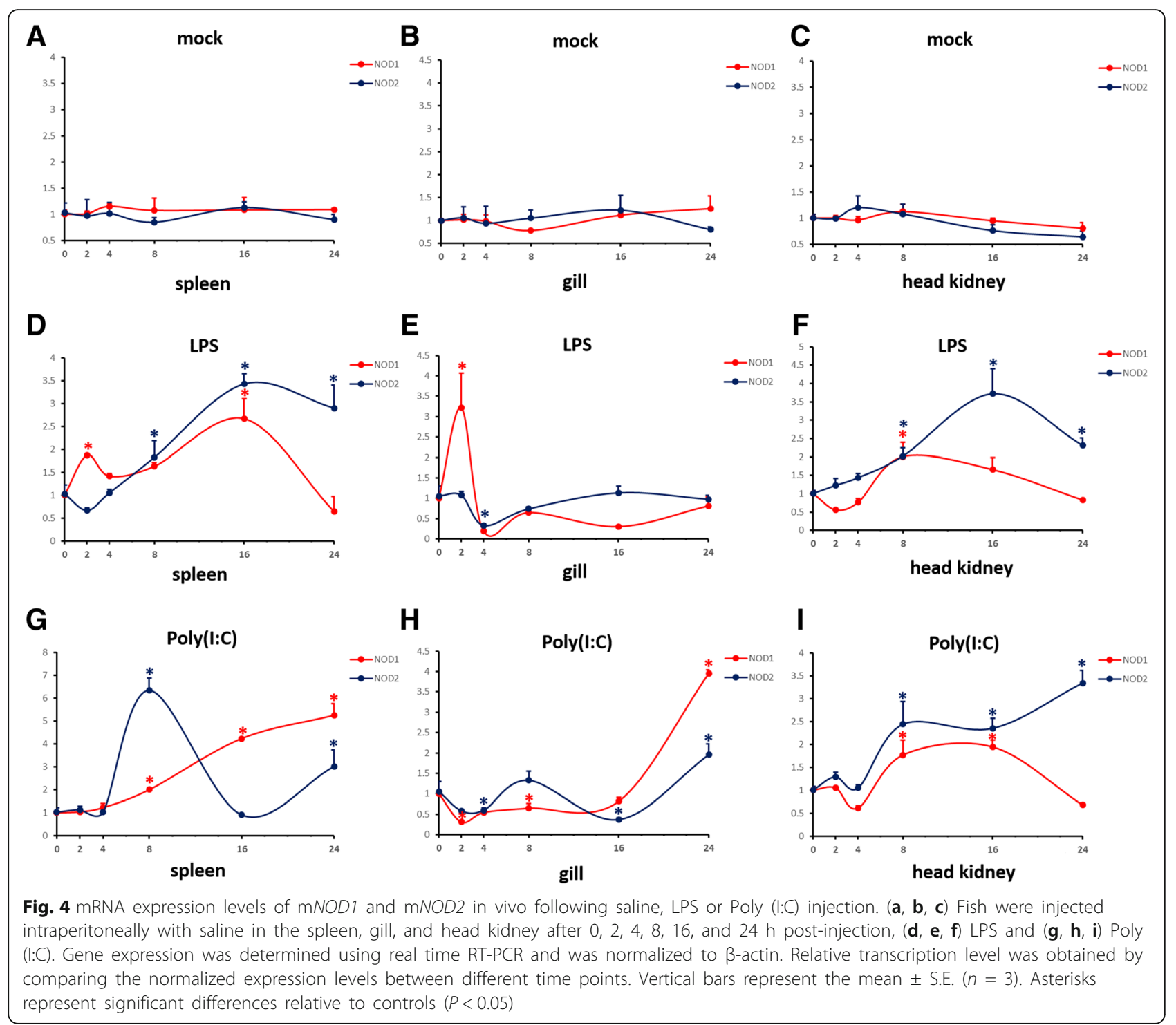

NOD2 was abundantly expressed, with the highest levels observed in spleen [21]. As an important immune organ of fish, the head kidney has high expression levels of NOD1 and NOD2, which is to be expected. In addition to the important immune organ, scattered lymphocyte germinal centers [35] are found in the mucous tissues of the gills, indicated that the gill might function as the first line of defense in the innate immune response, and high levels of NOD1 and NOD2 gene expression in the gill is also expected. Besides, the NOD1 and NOD2 genes of mandarinfish were also observed to be expressed at high levels in head kidney, speculating that NOD1 and NOD2 may take part in the anti-pathogen response.

NODs are a recently characterized group of pathogen recognition receptors, they are believed to be intracellular bacteria-recognizing receptor. The bacterial component, LPS, has been shown to influence NOD1 and NOD2 mRNA expression in mouse [36], rohu [37], and channel catfish [35]. In channel catfish, after bacterial induction, NOD1 and NOD2 were highly upregulated in head kidney and spleen [35]. A significant observation in this study was that the expression of NOD1 and NOD2 genes were upregulated in vivo following LPS stimulation, suggesting the involvement of these genes in antibacterial response. In addition, mandarinfish NOD2 was activated to a greater extent, but NOD1 peaked earlier than NOD2 after LPS induction in spleen, gill and head kidney, indicating that NOD1 and NOD2 appear to play a unique role in initially sensing pathogenic and may work in different response time in defense against bacterial invasion.

In addition, some studies have showed that NOD1 and NOD2 could prove to participate in antiviral defense, 
such as human [38], olive flounder [39], rohu [20], grouper [18] and grass carp [24]. In human, NOD1 was significantly induced following stimulation with human cytomegalovirus [38] and in grass carp activation of NOD1 and NOD2 was reported in reovirus infection [24]. In mandarinfish, both the NOD1 and NOD2 gene were found to be activated in viral infection, mimicked by treatment with the viral analogue Poly I:C, revealing that NODs are sensitive to the protective immune response against viral invasion. Interestingly, mandarinfish NOD2 showed a more significant increasement when stimulated by PolyI:C than did NOD1 in vivo, however, NOD1 showed significantly higher expression at $24 \mathrm{~h}$ post infection in spleen and gill during PolyI:C stimulation, demonstrating that mandarinfish NOD1 and NOD2 may act differently within different tissues in antiviral defense. In addition, the expression levels of mNOD1 and mNOD2 mRNA after LPS stimulation generally peaked at an earlier time point than that observed with Poly (I:C) treatment, revealing that both of them were more sensitive to the antibacterial sensitive response than to viral invasion, indicating that these proteins more easily identify bacterial peptidoglycans and induce signaling pathways by acting as PRRs [40, 41], meanwhile, some other subfamilies of NOD-like receptors may be responsible for inducing $m N O D 1$ and $m N O D 2$ in response to LPS [22], which needs further studies.

\section{Conclusions}

In summary, we first cloned and characterized the NOD1 and NOD2 cDNA sequences in mandarinfish, and demonstrated that the mandarinfish NOD1 and NOD2 genes are functionally similar to their counterparts from other teleosts. Transcriptional analysis showed ubiquitous expression of NOD1 and NOD2 gene in seven examined tissues. Expression analyses showed that NOD1 and NOD2 gene were significantly enhanced in vivo after LPS or Poly (I:C) stimulation, indicating that NOD1 and NOD2 may appear to play a unique role in initially sensing pathogenic and may work in different tissues in defense against bacterial and viral invasion. Taken together, our results revealed that the mNOD1 and $\mathrm{mNOD} 2$ might be involved in innate immune protection in mandarinfish.

\section{Additional file}

Additional file 1: Table S1. Primers used in the study. (DOCX 14 kb)

\section{Abbreviations}

BIR: Baculovirus inhibitor of apoptosis repeat; CARD: Caspase-activation and recruitment domain; CDD: Conserved Domains Database; CDS: Coding sequence; LPS: lipopolysaccharide; LRR: Leucine-rich repeat; NLRs: NOD-like receptors; ORF: Open reading frame; PAMP: Pathogen associated molecular patterns; PCR: Polymerase chain reaction; Poly (I:C): Polyriboinosinic polyribocytidylic acid; PRR: Pattern recognition receptors; RACE: Rapid amplification of cDNA ends; RLRs: RIG-1-like receptors; TLRs: Toll-like receptors

\section{Acknowledgements}

We are sincerely grateful to Prof Dr. Chen Guohong, Dr. Xu and all the teachers in our research team for their valuable guidance in the course of this research work. To all the members of the research team, we do appreciate the moral support and the immense support we received during the period of this research work.

\section{Funding}

This work was supported by the Priority Academic Program Development of Jiangsu Higher Education Institutions (2011-137). The funders had no role in the design of the study and collection, analysis, and interpretation of data and in writing the manuscript.

Availability of data and materials

The data sets supporting the results of this article are included within the article and its additional file.

\section{Authors' contributions}

GHC and QX conceived of the study, and participated in its design and coordination. TTG, LL, JWW, and LLT carried out the experiments. WZW and XSW participated in the design of the study and performed the statistical analysis. TTG and QX contributed to the manuscript preparation. QX and GHC interpreted the results and contributed to edit the manuscript. All authors read and approved the final manuscript.

\section{Ethics approval and consent to participate}

The animal experiment was reviewed and approved by the Institutional Animal Care and Use Committee of Yangzhou University (approval number: 151-2014). Procedures were performed in accordance with the Regulations for the Administration of Affairs Concerning Experimental Animals (Yangzhou University, China, 2012) and the Standards for the Administration of Experimental Practices (Jiangsu, China, 2008). And the mandarinfishes were obtained from the Gaoyou Dongshi Special Aquatic Products Company (Yangzhou, China). We also confirm that the field studies did not involve endangered or protected species.

Consent for publication

Not applicable.

\section{Competing interests}

The authors declare that they have no competing interests.

\section{Publisher's Note}

Springer Nature remains neutral with regard to jurisdictional claims in published maps and institutional affiliations.

Received: 13 February 2018 Accepted: 9 August 2018

Published online: 17 August 2018

References

1. Magnadóttir B. Innate immunity of fish (overview). Fish Shellfish Immunol. 2006;20(2):137.

2. Kawai T, Akira S. The roles of TLRs, RLRs and NLRs in pathogen recognition. Int Immunol. 2009;21(4):317.

3. Rothenfusser S, Goutagny N, Diperna G, Gong M, Monks BG, Schoenemeyer A, Yamamoto M, Akira S, Fitzgerald KA. The RNA helicase Lgp2 inhibits TLR-independent sensing of viral replication by retinoic acid-inducible gene-I. J Immunol. 2005;175(8):5260.

4. Akira S, Hemmi H. Recognition of pathogen-associated molecular patterns by TLR family. Immunol Lett. 2003;85(2):85-95.

5. Zou J, Chang M, Nie P, Secombes CJ. Origin and evolution of the RIG-I like RNA helicase gene family. BMC Evol Biol. 2009;9(1):85.

6. Moore CB, Ting JP. Regulation of mitochondrial antiviral signaling pathways. Immunity. 2008;28(6):735-9.

7. Kanneganti TD, Lamkanfi M, Núñez G. Intracellular NOD-like receptors in host defense and disease. Immunity. 2007;27(4):549-59. 
8. Chen G, Shaw MH, Kim YG, Nuñez G. NOD-like receptors: role in innate immunity and inflammatory disease. Annu Rev Pathol. 2009;4(4):365-98.

9. Hansen JD, Vojtech LN, Laing KJ. Sensing disease and danger: a survey of vertebrate PRRs and their origins. Dev Comp Immunol. 2011;35(9):886.

10. Carneiro LA, Magalhaes JG, Tattoli I, Philpott DJ, Travassos LH. Nod-like proteins in inflammation and disease. J Pathol. 2008;214(2):136-48.

11. Rosenstiel P, Jacobs G, Till A, Schreiber S. NOD-like receptors: ancient sentinels of the innate immune system. Cell Mol Life Sci Cmls. 2008;65(9):1361-77.

12. Jin C, Flavell RA. Inflammasome activation. The missing link: how the inflammasome senses oxidative stress. Immunol Cell Biol. 2010;88(5):510-2.

13. Tschopp J, Martinon F, Burns K. NALPs: a novel protein family involved in inflammation. Nat Rev Mol Cell Biol. 2003;4(2):95-104.

14. Strober W, Murray PJ, Kitani A, Watanabe T. Signalling pathways and molecular interactions of NOD1 and NOD2. Nature Rev Immunol. 2006;6(1):9.

15. Ogura Y, Inohara N, Benito A, Chen FF, Yamaoka S, Nunez G. Nod2, a Nod1/ Apaf-1 family member that is restricted to monocytes and activates NF-kappaB. J Biol Chem. 2001;276(7):4812.

16. Inohara N, Ogura Y, Fontalba A, Gutierrez O, Pons F, Crespo J, Fukase K, Inamura S, Kusumoto S, Hashimoto M. Host recognition of bacterial Muramyl dipeptide mediated through NOD2 IMPLICATIONS FOR CROHN'S DISEASE. J Biol Chem. 2003;278(8):5509-12.

17. Girardin SE, Boneca IG, Viala J, Chamaillard M, Labigne A, Thomas G, Philpott DJ, Sansonetti PJ. Nod2 is a general sensor of peptidoglycan through muramyl dipeptide (MDP) detection. J Biol Chem. 2003;278(11):8869-72.

18. Hou QH, Yi SB, Ding X, Zhang HX, Sun Y, Zhang Y, Liu XC, Lu DQ, Lin HR. Differential expression analysis of nuclear oligomerization domain proteins NOD1 and NOD2 in orange-spotted grouper (Epinephelus coioides). Fish Shellfish Immunol. 2012;33(5):1102-11.

19. Chang $M$, Wang $T$, Nie $P, Z$ Zou J, Secombes CJ. Cloning of two rainbow trout nucleotide-binding oligomerization domain containing 2 (NOD2) splice variants and functional characterization of the NOD2 effector domains. Fish Shellfish Immunol. 2011;30(1):118.

20. Swain B, Basu M, Samanta M. Molecular cloning and characterization of nucleotide binding and oligomerization domain-1 (NOD1) receptor in the Indian major carp, rohu (Labeo rohita), and analysis of its inductive expression and down-stream signalling molecules following ligands exposur. Fish Shellfish Immunol. 2012;32(5):899.

21. Swain B, Basu M, Samanta M. NOD1 and NOD2 receptors in mrigal (Cirrhinus mrigala): inductive expression and downstream signalling in ligand stimulation and bacterial infections. J Biosci. 2013;38(3):533-48.

22. Rajendran KV, Zhang J, Liu S, Kucuktas H, Wang X, Liu H, Sha Z, Terhune J, Peatman $E$, Liu Z. Pathogen recognition receptors in channel catfish: L. Identification, phylogeny and expression of NOD-like receptors. Dev Comp Immunol. 2012;37(1):77-86.

23. Xie J, Hodgkinson JW, Katzenback BA, Kovacevic N, Belosevic M. Characterization of three nod-like receptors and their role in antimicrobial responses of goldfish (Carassius auratus L.) macrophages to Aeromonas salmonicida and Mycobacterium marinum. Dev Comp Immunol. 2013;39(3):180-7.

24. Chen $\mathrm{WQ}, \mathrm{Xu} \mathrm{QQ}$, Chang MX, Nie P, Peng KM. Molecular characterization and expression analysis of nuclear oligomerization domain proteins NOD1 and NOD2 in grass carp Ctenopharyngodon idella. Fish Shellfish Immunol. 2010;28(1):18-29.

25. Park JH, Kim YG, Mcdonald C, Kanneganti TD, Hasegawa M, Body-Malapel M, Inohara N, Núñez G. RICK/RIP2 mediates innate immune responses induced through Nod1 and Nod2 but not TLRs. J Immunol. 2007;178(4):2380.

26. Inohara N, Koseki T, Del PL, Hu Y, Yee C, Chen S, Carrio R, Merino J, Liu D, Ni J. Nod1, an Apaf-1-like activator of caspase-9 and nuclear factor-kappaB. J Biol Chem. 1999;274(21):14560-7.

27. He JG, Weng SP, Huang ZJ, Zeng K. Identification of outbreak and infectious diseases pathogen of Siniperca chuatsi. Acta Nat Univ Sunyatseni. 1998; 37(5):74-4.

28. He JG, Wang SP, Zeng K, Huang ZJ, Chan SM. Systemic disease caused by an iridovirus-like agent in cultured mandarinfish, Siniperca chuatsi (Basilewsky), in China. J Fish Dis. 2000;23(3):219-22.

29. Langdon JS, Humphrey JD, Williams LM. Outbreaks of an EHNV-like iridovirus in cultured rainbow trout, Salmo gairdneri Richardson, in Australia. J Fish Dis. 1988;11(1):93-6.
30. Chou HY, Hsu CC, Peng TY. Isolation and characterization of a pathogenic Iridovirus from cultured grouper (Epinephelus sp.) in Taiwan. Fish Pathol. 1998;33(4):201-6.

31. Borzym E, Majpaluch J. Experimental infection with epizootic haematopoietic necrosis virus (EHNV) of rainbow trout (Oncorhynchus mykiss Walbaum) and European perch (Perca fluviatilis L.). Bull Vet Inst Pulawy. 2015;59(4):473-8.

32. Gao L, He C, Liu X, Su H, Gao X, Li Y, Liu W. The innate immune-related genes in catfish. Int J Mol Sci. 2012;13(11):14172.

33. Bonardi V, Cherkis K, Nishimura MT, Dangl JL. A new eye on NLR proteins: focused on clarity or diffused by complexity? Curr Opin Immunol. 2012;24(1):41-50.

34. Li J, Gao Y, Xu T. Comparative genomic and evolution of vertebrate NOD1 and NOD2 genes and their immune response in miiuy croaker. Fish Shellfish Immunol. 2015;46(2):387-97.

35. Sha Z, Abernathy JW, Wang S, Li P, Kucuktas H, Liu H, Peatman E, Liu Z. NOD-like subfamily of the nucleotide-binding domain and leucine-rich repeat containing family receptors and their expression in channel catfish. Dev Comp Immunol. 2009;33(9):991-9.

36. Iwanaga Y, Davey MP, Martin TM, Planck SR, Depriest ML, Baugh MM, Suing CM, Rosenbaum JT. Cloning, sequencing and expression analysis of the mouse NOD2/CARD15 gene. Inflamm Res. 2003;52(6):272-6.

37. Swain B, Basu M, Sahoo BR, Maiti NK, Routray P, Eknath AE, Samanta M. Molecular characterization of nucleotide binding and oligomerization domain (NOD)-2, analysis of its inductive expression and down-stream signaling following ligands exposure and bacterial infection in rohu (Labeo rohita). Dev Comp Immunol. 2012;36(1):93.

38. Fan YH, Roy S, Mukhopadhyay R, Kapoor A, Duggal P, Wojcik GL, Pass RF, Arav-Boger R. Role of nucleotide-binding oligomerization domain 1 (NOD1) and its variants in human cytomegalovirus control in vitro and in vivo. Proc Natl Acad Sci U S A. 2016;113(48):E7818.

39. Park SB, Hikima J, Suzuki Y, Ohtani M, Nho SW, Cha IS, Jang HB, Kondo H, Hirono I, Aoki T. Molecular cloning and functional analysis of nucleotidebinding oligomerization domain 1 (NOD1) in olive flounder, Paralichthys olivaceus. Dev Comp Immunol. 2012;36(4):680-7.

40. Berende A, Oosting M, Kullberg BJ, Netea MG, Joosten LA. Activation of innate host defense mechanisms by Borrelia. Eur Cytokine Netw. 2010;21(1):7-18.

41. Inohara N, Nuñez G. NODs: intracellular proteins involved in inflammation and apoptosis. Nat Rev Immunol. 2003;3(5):371-82.

\section{Ready to submit your research? Choose BMC and benefit from:}

- fast, convenient online submission

- thorough peer review by experienced researchers in your field

- rapid publication on acceptance

- support for research data, including large and complex data types

- gold Open Access which fosters wider collaboration and increased citations

- maximum visibility for your research: over $100 \mathrm{M}$ website views per year

At BMC, research is always in progress.

Learn more biomedcentral.com/submissions 